\title{
Agricultural use of DDT and risk of non-Hodgkin's lymphoma: pooled analysis of three case-control studies in the United States
}

\author{
Dalsu Baris, Shelia Hoar Zahm, Kenneth P Cantor, Aaron Blair
}

\begin{abstract}
Objectives-The objective of this pooled analysis was to examine whether exposure to DDT was associated with the risk of non-Hodgkin's lymphoma among male farmers.

Methods-Data from three case-control studies from four midwestern states in the United States (Nebraska, Iowa, Minnesota, Kansas) were pooled to carry out analyses of 993 cases and 2918 controls. Information on use of agricultural pesticides and other risk factors was based on interviews. Non-farmers (people who had never lived or worked on a farm) were used as a reference category.

Results-There were 161 cases and 340 controls who reported use of DDT on animals or crops, or on both, yielding an odds ratio $(O R)$ of 1.2 (95\% confidence intervals $(95 \% \mathrm{CI}) 1.0$ to 1.6$)$. Farmers who had used DDT for $\geqslant 15$ years had an OR of 1.5 (95\% CI 1.0 to 2.3). Adjustment for respondent status and use of other pesticides resulted in slightly reduced ORs. Analyses by the number of days of use a year was limited to the Nebraska data. The most notable increase was found among farmers who used DDT for $\geqslant 5$ days a year (OR 2.6, 95\% CI 1.1 to 5.9); however, additional adjustment for use of organophosphates, phenoxyacetic acids, and the individual pesticides lindane, malathion, and atrazine reduced the ORs to $1.0,0.9$, $1.1,1.6$, and 1.9 respectively.

Conclusions-No strong consistent evidence was found for an association between exposure to DDT and risk of non-Hodgkin's lymphoma. It seems that the excess risk initially found may be explained by use of other pesticides.
\end{abstract}

(Occup Environ Med 1998;55:522-527)

Keywords: case-control; non-Hodgkin's lymphoma; DDT

2,2-Bis (p-chlorophenyl)-1,1,1-trichloroethane (DDT), a chlorinated organic pesticide, was developed during the 1930s and became widely used in the 1960s worldwide. Early use was against insect borne diseases. In the 1960s in the United States, DDT was registered for use on 334 crops (Agency for Toxic Substance and Disease Registry, 1989) ${ }^{1}$ with a peak production of 80000 tonnes in 1963. In the 1970s, biological accumulation and long term toxicity of DDT were widely recognised, and the US Environmental Protection Agency (EPA) banned its use in 1972. It has been estimated that between 1940 and 1970 two million tonnes of DDT were used for insect control with $80 \%$ used in agriculture. Today, 25 years after the ban, DDT and its metabolites can be measured in almost $100 \%$ of human serum and adipose tissue samples taken, although the concentration has decreased over time. This indicates remarkable biological persistence. ${ }^{23}$

DDT has been shown to be a tumour promoter and has been classified as a "possible carcinogen" to humans (group 2B) by the International Agency for Research on Cancer. ${ }^{45}$ One of the cancers associated with DDT exposure in some studies is nonHodgkin's lymphoma. ${ }^{67}$ Because other studies have been negative, ${ }^{8-10}$ there is a need for additional evaluation of this issue.

In this paper, we report the results of a pooled analysis of three population based casecontrol studies conducted in Nebraska, ${ }^{11}$ Kansas, ${ }^{12}$ and Iowa and Minnesota. ${ }^{7}$ The study from Iowa and Minnesota demonstrated excess risk of lymphoma with use of DDT. Each study included several malignancies of the lymphatic and haematopoietic systems. The Kansas study also included soft tissue sarcoma. The pooled data allowed us to have many cases to evaluate the risk associated with DDT while controlling for exposure to other pesticides.

\section{Methods}

SELECTION OF CASES

In Nebraska, all cases of non-Hodgkin's lymphoma diagnosed between July 1983 and June 1986 among white subjects aged $\geqslant 21$ and living in one of the 66 counties of eastern Nebraska were identified through the Nebraska Lymphoma Study Group and area hospitals $(n=227)$. In this report, we excluded female cases and controls. In the Iowa and Minnesota Study, all newly diagnosed cases of nonHodgkin's lymphoma among white men aged $\geqslant 30$ were ascertained from records of the Iowa State Health Registry and a special surveillance system of Minnesota hospitals and pathology laboratories $(n=780)$. The diagnosis period was between October 1980 and September 1982 in Minnesota, and between March 1981 and October 1983 in Iowa. In Kansas, a random sample of cases among white men aged $\geqslant 21$ were selected from the statewide cancer registry run by the University of Kansas Cancer Data Service $(n=200)$. All eligible cases were reviewed by expert pathologists
Accepted

24 March 1998 
Table 1 Descriptive information on the general characteristics of cases and controls

\begin{tabular}{|c|c|c|c|c|c|c|}
\hline & \multicolumn{2}{|l|}{ Non-farmers } & \multicolumn{2}{|c|}{ Farmers (not used DDT) } & \multicolumn{2}{|c|}{ Farmers (used DDT) } \\
\hline & $\begin{array}{l}\text { Cases }(n=243) \\
n(\%)\end{array}$ & $\begin{array}{l}\text { Controls }(n=775) \\
n(\%)\end{array}$ & $\begin{array}{l}\text { Cases }(n=342) \\
n(\%)\end{array}$ & $\begin{array}{l}\text { Controls }(n=1081) \\
n(\%)\end{array}$ & $\begin{array}{l}\text { Cases }(n=161) \\
n(\%)\end{array}$ & $\begin{array}{l}\text { Controls }(n=340) \\
n(\%)\end{array}$ \\
\hline \multicolumn{7}{|l|}{ State of residence: } \\
\hline Nebraska & $54(22.22)$ & $184(23.74)$ & $56(16.37)$ & $244(22.57)$ & $35(21.74)$ & $92(27.06)$ \\
\hline Iowa & $69(28.40)$ & $144(18.58)$ & $95(27.78)$ & $193(17.85)$ & $61(37.89)$ & $117(34.41)$ \\
\hline Minnesota & $83(34.16)$ & $166(21.42)$ & $101(29.53)$ & $211(19.52)$ & $59(36.65)$ & 99 (29.12) \\
\hline Kansas & $37(15.23)$ & $281(36.26)$ & $90(26.32)$ & $433(40.06)$ & $6(3.73)$ & $32(9.41)$ \\
\hline \multicolumn{7}{|l|}{ Age: } \\
\hline $20-44$ & $37(15.23)$ & $181(23.35)$ & $26(7.60)$ & 99 (9.19) & $14(8.70)$ & $19(5.60)$ \\
\hline $45-64$ & $113(46.50)$ & $260(33.55)$ & $102(29.82)$ & $281(26.09)$ & $55(34.16)$ & $126(37.17)$ \\
\hline $65-74$ & $60(24.69)$ & $195(25.16)$ & $98(28.65)$ & $287(26.65)$ & $60(37.27)$ & $90(26.55)$ \\
\hline$\geqslant 75$ & $33(13.58)$ & $139(17.94)$ & $116(33.92)$ & $410(38.07)$ & $32(19.88)$ & $104(30.68)$ \\
\hline \multicolumn{7}{|l|}{ Respondent status: } \\
\hline Self respondents & $164(67.49)$ & $442(57.03)$ & $222(64.91)$ & $645(59.67)$ & $122(75.78)$ & $231(67.94)$ \\
\hline Proxy respondents & $79(32.51)$ & $333(42.97)$ & $120(35.09)$ & $436(40.33)$ & $39(24.22)$ & $109(32.06)$ \\
\hline \multicolumn{7}{|l|}{ Histological type: } \\
\hline Follicular & $76(31.28)$ & NA & $98(28.65)$ & NA & $47(29.19)$ & NA \\
\hline Diffuse & $90(37.04)$ & & $127(37.13)$ & & $53(32.92)$ & \\
\hline Small lymphocytic & $22(9.05)$ & & $44(12.87)$ & & $22(13.66)$ & \\
\hline Other & $55(22.63)$ & & $73(21.35)$ & & $39(24.22)$ & \\
\hline
\end{tabular}

$\mathrm{NA}=$ not applicable.

(pathological reviews were done in each study before pooling the data) and classified according to the working formulation ${ }^{13}{ }^{14}$ and only histologically confirmed cases were included in this analysis.

SELECTION OF CONTROLS

Controls were randomly selected from the same geographical areas as the cases with frequency matching by race, sex, age (five-year age groups), and vital status at the time of interview. For living cases aged $<65$ controls were selected by two stage random digit dialing. ${ }^{15}$ For living cases aged $\geqslant 65$ the controls were selected from the records of the Health Care Financing Administration (Medicare). For the deceased cases, the controls were selected from the state mortality files with additional matching for year of death. A total of 3379 controls (Nebraska 831, Iowa and Minnesota 1543, Kansas 1005) were identified.

INTERVIEWS

Interviews with 993 cases and 2918 controls were conducted with the subjects or their next of kin, if the subjects were dead or incapacitated. The interviews were done by telephone in Kansas and Nebraska and in person in Iowa and Minnesota. Among the four states, the interview response rate varied between $91 \%$ and $96 \%$ among cases and $78 \%$ and $94 \%$ among controls. In each study, detailed questions were asked on the use of agricultural pesticides as well as other known or suspected risk factors for non-Hodgkin's lymphoma. In Nebraska, information was obtained through direct questioning about the use of DDT including the total number of years of use and average number of days a year of use. In Kansas, use of DDT was assessed by an open ended question without prompting for specific pesticides. Duration of use and days of use a year were obtained for all insecticides as a group but not for DDT specifically. In Iowa and Minnesota, use was assessed by a direct question about DDT. Users were also asked the first and the last year of use of DDT. In each study, subjects were asked about use of protective equipment. The question was specific for individual pesticides in Iowa and Minnesota but was for

Table 2 Odds ratios (95\% CIs) for non-Hodgkin's lymphoma among male farmers according to using or handling DDT by state of residence

\begin{tabular}{|c|c|c|c|c|c|c|c|c|c|c|}
\hline & \multicolumn{2}{|c|}{ Nebraska* } & \multicolumn{2}{|l|}{ Iowa* } & \multicolumn{2}{|c|}{ Minnesota ${ }^{\star}$} & \multicolumn{2}{|c|}{ Kansas* } & \multicolumn{2}{|l|}{ Totalt } \\
\hline & Case & Controls & Cases & Controls & Cases & Controls & Cases & Controls & Cases & Controls \\
\hline Non-farmers (reference) & 54 & 184 & 69 & 144 & 83 & 166 & 37 & 281 & 243 & 775 \\
\hline OR & 1.0 & & 1.0 & & 1.0 & & 1.0 & & 1.0 & \\
\hline \multicolumn{11}{|l|}{ Farmers who did not use } \\
\hline DDT & 56 & 244 & 95 & 193 & 101 & 211 & 90 & 429 & 342 & 1077 \\
\hline OR $(95 \%$ CI $)$ & \multicolumn{2}{|c|}{$0.8(0.5$ to 1.3$)$} & \multicolumn{2}{|c|}{$1.1(0.8$ to 1.7$)$} & \multicolumn{2}{|c|}{$1.0(0.7$ to 1.5$)$} & \multicolumn{2}{|c|}{$1.5(1.0$ to 2.4$)$} & \multicolumn{2}{|c|}{$1.1(0.9$ to 1.4$)$} \\
\hline \multicolumn{11}{|c|}{ DDT use on crops and animals: } \\
\hline Used DDT & 35 & 92 & 61 & 117 & 59 & 99 & 6 & 32 & 161 & 340 \\
\hline OR $(95 \% \mathrm{CI})$ & \multicolumn{2}{|c|}{$1.4(0.8$ to 2.2$)$} & \multicolumn{2}{|c|}{$1.1(0.7$ to 1.7$)$} & \multicolumn{2}{|c|}{$1.3(0.8$ to 2.0$)$} & \multirow{2}{*}{\multicolumn{2}{|c|}{$1.4(0.6$ to 3.7$)$}} & \multicolumn{2}{|c|}{$1.2(1.0$ to 1.6$)$} \\
\hline Handled DDT & 30 & 81 & 55 & 106 & 55 & 88 & & & 140 & 275 \\
\hline OR $(95 \% \mathrm{CI})$ & \multicolumn{2}{|c|}{$1.3(0.8$ to 2.3$)$} & \multicolumn{2}{|c|}{$1.1(0.7$ to 1.7$)$} & \multicolumn{2}{|c|}{$1.4(0.9$ to 2.1$)$} & \multicolumn{2}{|l|}{ NA } & \multicolumn{2}{|c|}{$1.3(1.0$ to 1.6$)$} \\
\hline \multicolumn{11}{|l|}{ DDT use on animals: } \\
\hline Used DDT & 19 & 48 & 35 & 85 & 50 & 75 & 6 & 28 & 110 & 236 \\
\hline OR $(95 \% \mathrm{CI})$ & \multicolumn{2}{|c|}{$1.4(0.8$ to 2.6$)$} & \multicolumn{2}{|c|}{$0.9(0.5$ to 1.4$)$} & \multicolumn{2}{|c|}{$1.4(0.9$ to 2.2$)$} & \multicolumn{2}{|c|}{$1.6(0.6$ to 4.2$)$} & \multicolumn{2}{|c|}{$1.2(0.9$ to 1.6$)$} \\
\hline Handled DDT & 17 & 43 & 31 & 81 & 48 & 68 & \multirow{2}{*}{\multicolumn{2}{|c|}{ NA }} & 96 & 192 \\
\hline OR $(95 \% \mathrm{CI})$ & \multicolumn{2}{|c|}{$1.4(0.7$ to 2.7$)$} & \multicolumn{2}{|c|}{$0.8(0.5$ to 1.3$)$} & \multicolumn{2}{|c|}{$1.5(1.0$ to 2.4$)$} & & & \multicolumn{2}{|c|}{$1.2(0.9$ to 0.6$)$} \\
\hline DDT use on crops: & & & & & & & & & & \\
\hline Used DDT & 8 & 21 & 39 & 61 & 26 & 31 & 1 & 4 & 74 & 117 \\
\hline OR $(95 \% \mathrm{CI})$ & 1.3 & to 3.2 ) & 1.4( & to 2.3 ) & 1.9 & 0 to 3.4$)$ & 2.0 & 2 to 18.2 ) & 1.5 & 1 to 2.1 ) \\
\hline Handled DDT & 6 & 20 & 35 & 52 & 22 & 23 & & & 63 & 95 \\
\hline OR $(95 \% \mathrm{CI})$ & 1.1 & to 2.8 ) & 1.4( & to 2.4 ) & 2.1 & 1 to 4.1 ) & NA & & 1.6 & 1 to 2.3 ) \\
\hline
\end{tabular}

*Adjusted for age.

tAdjusted for age and state of residence.

$\mathrm{NA}=$ not applicable. 
Table 3 Odds ratios* (95\% CIs) for non-Hodgkin's lymphoma among DDT users by respondent status

\begin{tabular}{|c|c|c|c|c|c|c|c|c|c|c|}
\hline & \multicolumn{2}{|c|}{ Nebraska* } & \multicolumn{2}{|l|}{ Iowa ${ }^{\star}$} & \multicolumn{2}{|c|}{ Minnesota ${ }^{\star}$} & \multicolumn{2}{|c|}{ Kansas* } & \multicolumn{2}{|c|}{ Totalt } \\
\hline & Cases & Controls & Cases & Controls & Cases & Controls & Cases & Controls & Cases & Controls \\
\hline $\begin{array}{l}\text { Non-farmers } \\
\text { (reference) }\end{array}$ & 54 & 184 & 69 & 144 & 83 & 166 & 37 & 281 & 243 & 775 \\
\hline Odds ratio & \multicolumn{2}{|l|}{1.0} & \multicolumn{2}{|l|}{1.0} & \multicolumn{2}{|l|}{1.0} & \multicolumn{2}{|l|}{1.0} & \multicolumn{2}{|c|}{1.0} \\
\hline Self respondents & 25 & 64 & 50 & 89 & 41 & 55 & 5 & 19 & 122 & 231 \\
\hline OR $(95 \% \mathrm{CI})$ & \multicolumn{2}{|c|}{$1.4(0.8$ to 2.4$)$} & \multicolumn{2}{|c|}{$1.2(0.7$ to 1.8$)$} & \multicolumn{2}{|c|}{$1.4(0.9$ to 2.3$)$} & \multicolumn{2}{|c|}{$2.0(0.7$ to 5.7$)$} & \multicolumn{2}{|c|}{$1.3(1.0$ to 1.8$)$} \\
\hline \multicolumn{11}{|c|}{ Proxy respondents: } \\
\hline Wives & 8 & 16 & 4 & 12 & 9 & 14 & 0 & 5 & 21 & 47 \\
\hline OR (95\% CI) & \multicolumn{2}{|c|}{$1.8(0.7$ to 4.5$)$} & \multicolumn{2}{|c|}{$0.9(0.3$ to 2.8$)$} & \multicolumn{2}{|c|}{$1.2(0.5$ to 3.0$)$} & \multicolumn{2}{|l|}{ - } & \multicolumn{2}{|c|}{$1.2(0.7$ to 2.1$)$} \\
\hline Other relatives & 2 & 12 & 6 & 16 & 9 & 26 & 1 & 7 & 18 & 61 \\
\hline OR $(95 \% \mathrm{CI})$ & \multicolumn{2}{|c|}{$0.7(0.1$ to 3.2$)$} & \multicolumn{2}{|c|}{$1.1(0.4$ to 1 to 3.2$)$} & \multicolumn{2}{|c|}{$0.8(0.3$ to 1.8$)$} & \multicolumn{2}{|c|}{$0.9(0.1$ to 7.5$)$} & \multicolumn{2}{|c|}{$0.8(0.5$ to 1.5$)$} \\
\hline
\end{tabular}

†Adjusted for age and state of residence.

all pesticides as a group in Kansas and Nebraska. Information on days of use a year, collected from Iowa subjects four years after the original interview, ${ }^{16}$ were not included in the pooled analysis because of a higher proportion of proxy respondents among cases $(55 \%)$ than among controls $(28 \%)$ at reinterview.

\section{STATISTICAL ANALYSIS}

Logistic regression analyses were used to obtain odds ratios (ORs) and $95 \%$ confidence intervals $(95 \% \mathrm{CIs})$, with a SAS program. ${ }^{17}$ Non-farmers (people who had never lived or worked on a farm) were selected as the reference population. Subjects who had lived or worked on a farm before the age of 18 but not $\geqslant 6$ months after the age of 18 , and subjects who did not have any information on the use of DDT, were excluded from the pooled data set $(\mathrm{n}=969)$ leaving 746 cases and 2196 controls eligible for the analysis.

\section{Results}

Table 1 presents descriptive data for cases and controls by state of residence, age category, respondent status, and by histological type of non-Hodgkin's lymphoma. Proxy interviews were conducted for $24 \%-43 \%$ of the subjects. Follicular and diffuse histology each represents about $30 \%$ of the cases.

There were 161 cases and 340 controls who reported use of DDT on animals or crops, or on both, yielding an overall non-significant OR of 1.2 ( $95 \%$ CI 1.0 to 1.6 ) (table 2 ). The OR was slightly lower (OR 1.1, 95\% CI 0.9 to 1.4 ) for farmers who did not use DDT. The OR was 1.3 (95\% 1.0 to 1.6$)$ for subjects who reported that they had personally handled DDT. Among farmers who reported use of DDT on animals or crops, or on both, the state specific ORs ranged from $1.1(95 \%$ CI 0.7 to 1.7$)$ for Iowa to 1.4 for Nebraska (95\% CI 0.8 to 2.2 ) or Kansas (95\% CI 0.6 to 3.7). The highest OR was 2.1 (95\% CI 1.1 to 4.8 ) among Minnesota farmers who personally handled DDT for use on animals. The ORs were slightly higher for use on crops than on animals. Some farmers used DDT on both animals and crops; therefore, these categories are not mutually exclusive. The ORs were similar among farmers who personally handled DDT and those who reported use on their farm but did not personally engage in mixing or application. In Kansas, however, the information on personal handling was for their usual practice for pesticides in general. The remaining analyses focus on use of DDT, regardless of personal handling or use on crops or animals so as to maximise the statistical power for more detailed analyses.

Table 3 shows ORs by respondent status. For all the states combined, use of DDT was associated with an OR of 1.3 (95\% CI 1.0 to 1.8 ) among self respondents and an OR of $1.2(95 \%$ CI 0.7 to 2.1) among proxy respondents (wives) and 0.8 (95\% CI 0.5 to 1.5 ) among other relatives. In state specific analyses, ORs by respondent status varied little.

Table 4 shows the ORs for non-Hodgkin's lymphoma by histological type and by family history of haematopoietic cancers. There was little variation by histological type, although the OR for small cell lymphoma was the largest (OR 1.6, 95\% CI 0.8 to 2.9). Farmers who had one or more first degree relatives with a history of haematopoietic cancer had a higher OR (OR 1.6, $95 \% 0.6$ to 4.8 ) than those who had a negative family history (OR 1.2, $95 \%$ CI 0.9 to 1.6$)$.

Table 4 Odds ratios $(95 \% \mathrm{CIs})^{\star}$ for non-Hodgkin's lymphoma among male farmers by histological type and family history of haematopoetic cancers

\begin{tabular}{|c|c|c|c|c|c|c|c|c|c|c|c|c|}
\hline & \multirow{2}{*}{\multicolumn{2}{|c|}{ Follicular type }} & \multirow{2}{*}{\multicolumn{2}{|c|}{ Diffuse type }} & \multirow{2}{*}{\multicolumn{2}{|c|}{$\begin{array}{l}\text { Small lymphocytic } \\
\text { type }\end{array}$}} & \multirow{2}{*}{\multicolumn{2}{|c|}{ Other type }} & \multicolumn{4}{|c|}{$\begin{array}{l}\text { History of first degree relative(s) with } \\
\text { haematopoetic cancer }\end{array}$} \\
\hline & & & & & & & & & \multicolumn{2}{|c|}{ Negative history } & \multicolumn{2}{|c|}{ Positive history } \\
\hline & $\begin{array}{l}\text { Cases } \\
(n)\end{array}$ & $\begin{array}{l}\text { OR } \\
(95 \% C I)\end{array}$ & $\begin{array}{l}\text { Cases } \\
(n)\end{array}$ & $\begin{array}{l}\text { OR } \\
(95 \% C I)\end{array}$ & $\begin{array}{l}\text { Cases } \\
(n)\end{array}$ & $O R$ & $\begin{array}{l}\text { Cases } \\
(n)\end{array}$ & $\begin{array}{l}\text { OR } \\
(95 \% C I)\end{array}$ & $\begin{array}{l}\text { Cases } \\
(n)\end{array}$ & $\begin{array}{l}\text { OR } \\
(95 \% C I)\end{array}$ & $\begin{array}{l}\text { Cases } \\
(n)\end{array}$ & $\begin{array}{l}\text { OR } \\
(95 \% C I)\end{array}$ \\
\hline $\begin{array}{l}\text { Non-farmers } \\
\quad \text { (reference) }\end{array}$ & 76 & 1.0 & 90 & 1.0 & 22 & 1.0 & 55 & 1.0 & 225 & 1.0 & 16 & 1.0 \\
\hline $\begin{array}{l}\text { Farmers who did } \\
\text { not use DDT }\end{array}$ & 98 & $\begin{array}{l}1.2 \\
(0.9 \text { to } 1.7)\end{array}$ & 127 & $\begin{array}{l}1.0 \\
(0.8 \text { to } 1.4)\end{array}$ & 44 & $\begin{array}{l}1.3 \\
(0.7 \text { to } 2.2)\end{array}$ & 73 & $\begin{array}{l}1.0 \\
(0.7 \text { to } 1.4)\end{array}$ & 315 & $\begin{array}{l}1.1 \\
(0.9 \text { to } 1.4)\end{array}$ & 21 & $\begin{array}{l}0.9 \\
(0.4 \text { to } 2.3)\end{array}$ \\
\hline $\begin{array}{l}\text { Farmers who } \\
\text { used DDT }\end{array}$ & 47 & $\begin{array}{l}1.3 \\
(0.8 \text { to } 1.9)\end{array}$ & 53 & $\begin{array}{l}1.2 \\
(0.8 \text { to } 1.7)\end{array}$ & 22 & $\begin{array}{l}1.6 \\
(0.8 \text { to } 2.9)\end{array}$ & 39 & $\begin{array}{l}1.3 \\
(0.8 \text { to } 2.0)\end{array}$ & 142 & $\begin{array}{l}1.2 \\
(0.9 \text { to } 1.6)\end{array}$ & 17 & $\begin{array}{l}1.6 \\
(0.6 \text { to } 4.8)\end{array}$ \\
\hline
\end{tabular}

^ Nebraska, Iowa/Minnesota, Kansas, ORs adjusted for age and state of residence. 
Table 5 Odds ratios* (95\% CIs) for non-Hodgkin's lymphoma among male farmers according to use of DDT adjusted for use of other pesticides

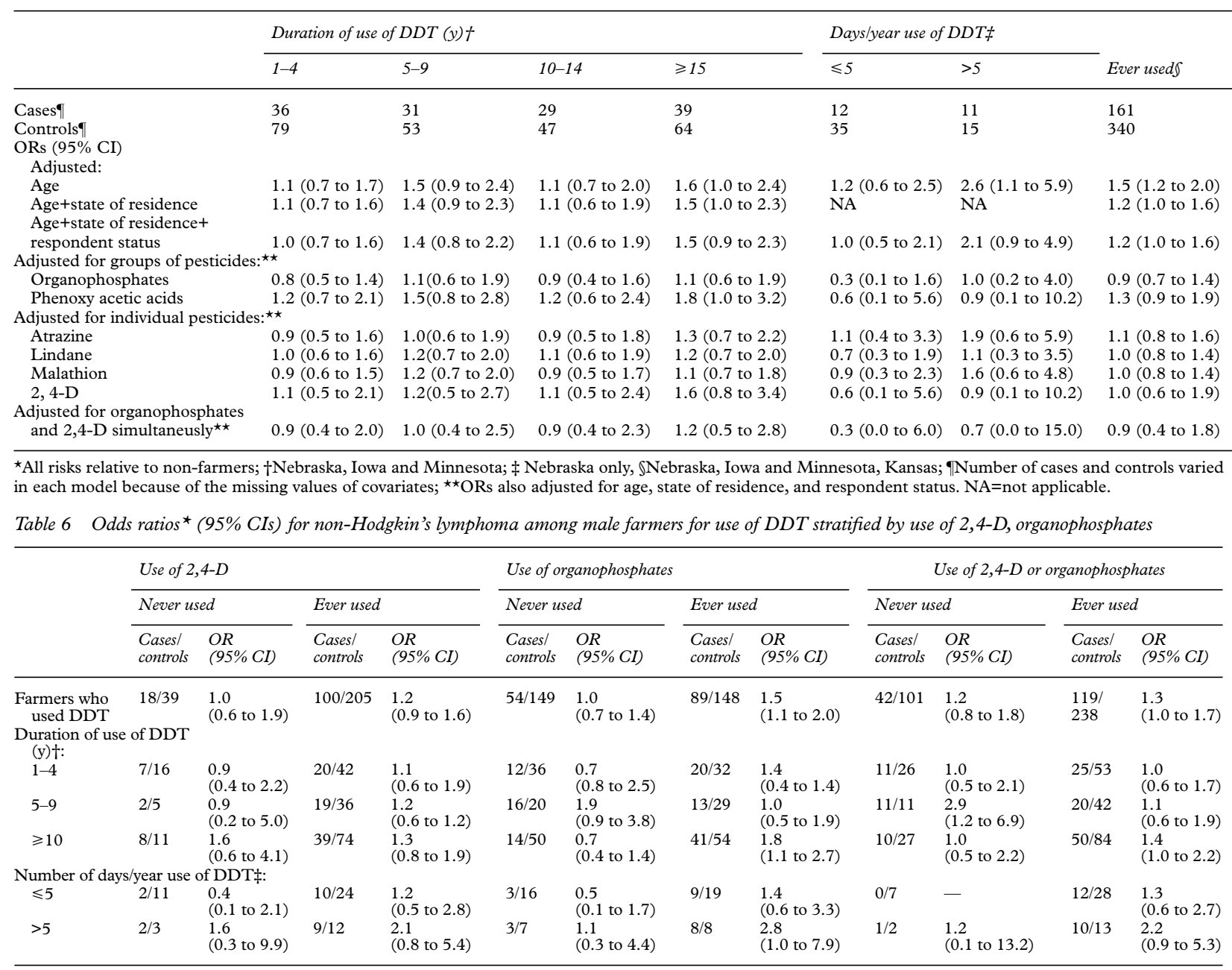

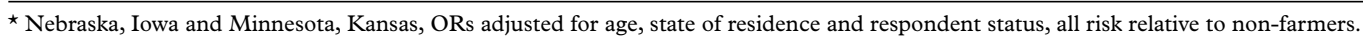
†Nebraska, Iowa and Minnesota, ORs adjusted for age, state of residence, and respondent status. $\ddagger$ Nebraska only, ORs adjusted for age and respondent status.

Farmers who first used DDT before 1965 showed slightly lower ORs than farmers who first used DDT after 1965 (OR 1.2, 95\% CI 0.9 to $1.6 v$ OR $1.4,95 \%$ CI 0.7 to 2.9 ). Farmers who did not use protective equipment had a higher OR (OR 1.4, $95 \%$ CI 1.0 to 1.8 ) for non-Hodgkin's lymphoma than those who used protective equipment (OR 0.9, 95\% CI 0.6 to 1.5 , data not shown).

Table 5 presents the ORs for non-Hodgkin's lymphoma by duration (number of years of use) and frequency (number of days of use a year) of use of DDT.

DURATION ANALYSIS (NUMBER OF YEARS OF USE) Based on data from Nebraska, Iowa, and Minnesota, farmers who had used DDT for $\geqslant 15$ years had a non-significant OR of 1.6 (95\% CI 1.0 to 2.4 , adjusted for age only). Additional adjustment for state of residence and respondent status had little effect on the OR. Adjustment for use of phenoxy acetic acids (as a group) increased the OR to 1.8 (95\% CI 1.0 to 3.2). Adjusting separately for use of the organophosphates lindane and atrazine decreased the OR. Adjusting for 2,4-dichlorophenoxyacetic acid $(2,4-\mathrm{D})$ did not change the results.
FREQUENCY ((NUMBER OF DAYS OF USE A YEAR) Based on Nebraska data only, non-Hodgkin's lymphoma was increased among farmers who used DDT for $>5$ days a year (OR 2.6, 95\% CI 1.1 to 5.9). An additional adjustment for respondent status reduced this OR to 2.1 (95\% CI 0.9 to 4.9). Individual adjustments for use of organophosphates, phenoxyacetic acids, lindane, malathion, or atrazine further reduced the ORs to values between 0.9 and 1.9. Simultaneous adjustment for organophosphates and 2,4-D resulted in an OR of 0.7 among farmers who used DDT for $>5$ days a year.

Table 6 presents ORs by duration and frequency of use of DDT among farmers who used it, and by the use of 2,4-D or organophosphates. Risk was higher among farmers who used DDT and also used 2,4-D (OR 1.2, 95\% 0.9 to 1.6$)$ than among farmers who used DDT but not 2,4-D (OR $1.095 \% 0.6$ to 1.9 ). A similar pattern was found for the use of organophosphates. Farmers who used DDT and used either 2,4-D or organophosphates had a slightly higher OR (OR 1.3, $95 \% 1.0$ to 1.7) than farmers who used DDT but never used 2,4-D or organophosphates (OR 1.2, $95 \%$ CI 0.8 to 1.8 ). Duration and frequency analyses showed a similar pattern. There was 
one notable exception: farmers who used DDT for $\geqslant 10$ years but never used $2,4-\mathrm{D}$ or organophosphates had a higher OR

(OR 2.9, 95\% CI 1.2 to 6.9) than farmers who used DDT and 2,4-D or organophosphates (OR $1.1,95 \%$ CI 0.6 to 1.9 ).

\section{Discussion}

The combined data set included data from three case-control studies conducted in $\mathrm{Ne}$ braska, Iowa, Minnesota, and Kansas. Our main motivation for the pooled analysis was to conduct a more detailed analysis than was possible for individual studies, and to adjust ORs for possible confounding effects from exposure to other pesticides.

Overall, we found a small non-significant OR of 1.2 between the use of DDT and the risk of non-Hodgkin's lymphoma among male farmers who ever used DDT. Adjusting for age, state of residence, respondent status, and use of other pesticides generally reduced the OR to near unity. Some of these pesticides - such as phenoxy acid herbicides, organophosphates; and individual pesticides such as 2,4-D, atrazine, lindane and malathion-were found in earlier studies to be associated with nonHodgkin's lymphoma. ${ }^{11}{ }^{18-20}$ In our analyses, the OR was 1.7

(95\% CI 1.1 to 2.5 ) for organophosphates and the risk remained after adjusting for DDT

(OR 1.5, $95 \%$ CI 1.0 to 2.31 ). This pattern was similar for lindane and malathion.

There was about a 1.5-fold to twofold increased risk among farmers who used DDT for $\geqslant 15$ years and among farmers who used DDT $>5$ days a year, but these associations generally diminished after adjusting for other pesticides. The most dramatic reduction was among the Nebraska subjects. Among farmers who used DDT for $>5$ days a year, the OR dropped from 2.1 to 0.9 after adjusting for use of phenoxy acetic acid or for $2,4-\mathrm{D}$ in this group.

Based on these results, it seems that the excess risk initially found for DDT may be due to the use of other pesticides shown to be associated with non-Hodgkin's lymphoma.

Our data are consistent with two recent studies that evaluated concentrations of DDT in serum and risk of non-Hodgkin's lymphoma. A Swedish study found no association between the DDE

(the major metabolite of DDT) concentration in adipose tissue and risk of non-Hodgkin's lymphoma. ${ }^{21}$ In a nested case-control study of 74 cases and 147 matched controls, conducted in the United States, no association was found between measured prediagnostic serum DDT concentrations and risk of non-Hodgkin's lymphoma. ${ }^{10}$

POSSIBLE SOURCES OF BIAS

Misclassification of exposure could have occurred from using a questionnaire as a tool to assess exposure to DDT and may affect the estimates of relations. If misclassification were non-differential by case-control status, its effect would be to bias the risk estimates towards the null. Without a doubt this occurs.
The level, however, is unclear. Associations between non-Hodgkin's lymphoma and other pesticides have been reported from these studies, ${ }^{6111720}$ and there is no reason to suspect that DDT reporting is inferior to the reporting of other chemicals; however, some misclassification might have occurred because DDT was banned in 1972. Also, Kansas data might have been more prone to misclasssification of exposure as days of use a year of pesticides refers to all pesticides and not DDT specifically.

Including farmers who lived or worked on farms where DDT was used but who did not personally handle the insecticide maximised the sample size but might have introduced an additional misclassification of exposure. However, the state specific and combined ORs for farmers who reported use of DDT on their farm instead of handling were not different from the ORs among those who personally handled DDT.

Some analyses relied on a few cases of nonHodgkin's lymphoma. This resulted in wide confidence intervals especially for the analysis of frequency of use

(number of days of use a year), based solely on data from Nebraska.

There are some limitations of using dead controls, particularly if the study exposure is likely to be associated with overall mortality. ${ }^{22} 23$ Studies evaluating these exposures would overestimate exposure levels in controls if dead controls were used. This would eliminate a true association or create a false negative association between these variables and the outcome. In the case of exposure to DDT, however, there is no reason to think that the dead controls had higher exposure to DDT than live controls. We assumed that the dead controls had the same distribution of use of DDT as the study base population, and use of DDT was not positively associated with overall mortality.

\section{Conclusion}

Our data provided no strong evidence that DDT was associated with non-Hodgkin's lymphoma among male farmers. We found some excess among farmers with longer or more frequent exposure to DDT, but it largely disappeared after adjusting for the use of other pesticides. The relatively large number of exposed cases and controls in this pooled analysis provided analytical opportunities which were not available in individual studies.

\footnotetext{
1 Agency for Toxic Substances and Disease Registry. Toxicological profile for $p, p^{\prime}-D D T, p, p^{\prime}-D D E$, and $p, p^{\prime}-D D D$. Springfield, VA: National Technological Information Service, 1989

2 Kutz FW, Wood PH, Baltimore DP. Organochlorine pesticides and polychlorinated biphenyls in human adipose tissue. Rev Environ Contam Toxicol 1991;120:1-87.

3 Murphy R, Harvey C. Residues and metabolites of selected persistent halogenated hydrocarbons in blood samples from a general population survey. Environ Health Perspect 1985;60:115-20.

4 International Agency for Research on Cancer. IARC Monographs on the Evaluation of Carcinogenic Chemicals to Humans. Vol 53. Lyon: IARC, 1991.

5 International Agency for Research on Cancer. IARC Monographs on the Evaluation of Carcinogenic Carcinogenic Chemigraphs on the Evaluation of Carcinogenic Carcin
cals to Humans. Vol 41 . Lyon: IARC, 1986.

6 Woods JS, Polissar L, Severson RK, et al. Soft tissue sarcoma and non-Hodgkin's lymphoma in relation to phenoxyherbicides and chlorinated phenol exposure in western Washington. $\mathcal{F}$ Natl Cancer Inst 1987;78:899-910.
} 
7 Cantor KP, Blair, A. Gibson R, et al. Pesticide and other agricultural risk factors for non-Hodgkin's lymphoma among men

8 Hardell L, Errikson M, Lenner P, et al. Malignant lymphoma and exposure to chemicals, especially organic solvents, chlorophenols and phenoxy acids: a case-control study. Brf Cancer 1981;43:169-76.

9 Hardell L, Eriksson M, Degerman A. Exposure to phenoxy acids, chlorophenols, or organic solvents in relation to histopathology, stage and anatomical localization of nonHodgkin's lymphoma. Cancer Res 1994;54:2386-9.

10 Rothman N, Cantor KP, Blair A, et al. A nested case-control study of non-Hodgkin's lymphoma and serum organochlorine residues. Lancet 1997;350:240-4.

$11 \mathrm{Zahm}$ SH, Weisenburger DD, Babbitt PA, et al. A case-control study of non-Hodgkin's lymphoma and the herbicide 2,4-dichlorophenoxyacetic acid (2,4-D) in eastern Nebraska. Epidemiology 1990;1:349-56.

12 Hoar SK, Blair, Holmes FF, et al. Agricultural herbicide use and risk of lymphoma and soft tissue sarcoma. $7 A M A$ and risk of lymp

13 Non-Hodgkin's lymphoma pathologic classification project. National Cancer Institute sponsored study of classification of non-Hodgkin's lymphomas: summary and description of a working formulation for clinical usage. Cancer 1982;49: 2112-35

14 Dick FR, Van Lier SF, McKeen K, et al. Non-concurrence in abstracted diagnosis of non-Hodgkin's lymphoma. $\mathcal{F}$ Nat Cancer Inst 1987;78:675-8.
15 Waksberg J. Sampling methods from random digit dialing. fournal of the American Statistical Association 1978;73:406.

16 Cantor KP, Blair A, Brown LM, et al. Pesticides and other agricultural risk factors for non-Hodgkin's lymphoma among men in Iowa and Minnesota. Cancer Res 1993;53: 2421.

17 SAS. SAS Language: reference version 6, 1st ed. NC: SAS, 1990.

18 Blair A, Zahm SH. Cancer among farmers. Occup Med 1991;6:335-54.

19 Zahm SH, Weisenburger DD, Cantor KP, et al. Role of herbicide atrazine in the development of non-Hodgkin's lymphoma. Scand f Work Environ Health 1993;19:108-14.

20 Blair A, Cantor KP, Zahm SH. Non-Hodgkin's lymphoma and agricultural use of the insecticide lindane. Am $\mathcal{F}$ Ind Med 1998;33:82-7.

21 Hardell L, Van Bavel B, Lindström G, et al. Higher concentrations of specific polychlorinated biphenyl congeners in adipose tissue from non-Hodgkin's lymphoma patients compared with controls without a malignant disease. International fournal of Oncology 1996;9:603-8.

22 McLaughlin JK, Blot WJ, Mehl ES, et al. Problems in the use of dead control in the case-control studies I. General results. Am F Epidemiol 1985;121:131-9.

23 Wacholder S, McLaughlin JK, Silverman DT, et al. Selection of controls in case control studies. 1. Principles. Am f Epidemiol 1992;135:1019-41.

\section{Vancouver style}

All manuscripts submitted to Occup Environ Med should conform to the uniform requirements for manuscripts submitted to biomedical journals (known as the Vancouver style.)

Occup Environ Med, together with many other international biomedical journals, has agreed to accept articles prepared in accordance with the Vancouver style. The style (described in full in the $\mathcal{F} A M A[1]$ ) is intended to standardise requirements for authors, and is the same as in this issue.

References should be numbered consecutively in the order in which they are first mentioned in the text by Arabic numerals on the line in square brackets on each occasion the reference is cited (Manson[1] confirmed other reports[2][3][4][5]). In future references to papers submitted to Occup Environ Med should include: the names of all authors if there are three or less or, if there are more, the first three followed by et al; the title of journal articles or book chapters; the titles of journals abbreviated according to the style of Index Medicus; and the first and final page numbers of the article or chapter. Titles not in Index Medicus should be given in full.

Examples of common forms of references are:

1 International Committee of Medical Journal Editors. Uniform requirements for manuscripts submitted to biomed journals. FAMA 1993;269:2282-6.

2 Soter NA, Wasserman SI, Austen KF. Cold urticaria: release into the circulation of histmaine and eosinophil chemotactic factor of anaphylaxis during cold challenge. N Engl F Med 1976;294:687-90.

3 Weinstein L, Swartz MN. Pathogenic properties of invading micro-organisms. In: Sodeman WA Jr, Sodeman WA, eds. Pathologic physiology, mechanisms of disease. Philadelphia: W B Saunders, 1974:457-72. 